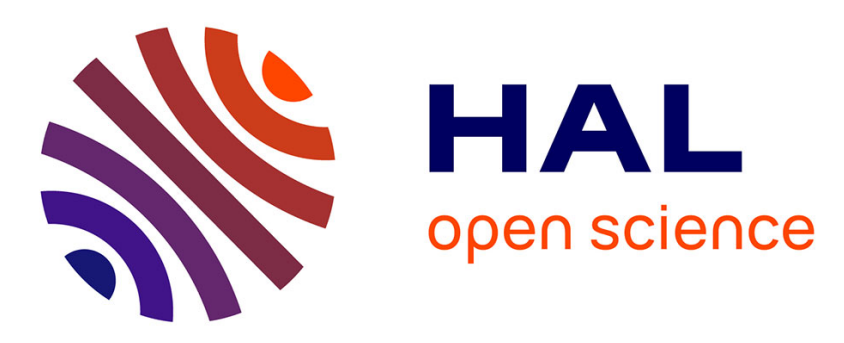

\title{
5000 years of lacustrine ecosystem changes from Lake Petit (Southern Alps, 2200m a.s.l.): Regime shift and resilience of algal communities
}

Rosine Cartier, Elodie Brisset, Christine Paillès, Frédéric Guiter, Florence Sylvestre, Florence Ruaudel, Edward J. Anthony, Cécile Miramont

\section{To cite this version:}

Rosine Cartier, Elodie Brisset, Christine Paillès, Frédéric Guiter, Florence Sylvestre, et al.. 5000 years of lacustrine ecosystem changes from Lake Petit (Southern Alps, 2200m a.s.l.): Regime shift and resilience of algal communities. The Holocene, 2015, 25 (8), pp.1231-1245. 10.1177/0959683615580862 . hal-01444813

\section{HAL Id: hal-01444813 https://hal.science/hal-01444813}

Submitted on 30 Apr 2020

HAL is a multi-disciplinary open access archive for the deposit and dissemination of scientific research documents, whether they are published or not. The documents may come from teaching and research institutions in France or abroad, or from public or private research centers.
L'archive ouverte pluridisciplinaire HAL, est destinée au dépôt et à la diffusion de documents scientifiques de niveau recherche, publiés ou non, émanant des établissements d'enseignement et de recherche français ou étrangers, des laboratoires publics ou privés. 


\title{
5000 years of lacustrine ecosystem changes from Lake Petit (Southern Alps, $2200 \mathrm{~m}$ a.s.I.): Regime shift and resilience of algal communities
}

\author{
Rosine Cartier, ${ }^{1,2}$ Elodie Brisset, ${ }^{1,2}$ Christine Paillès, ' Frédéric \\ Guiter, ${ }^{2}$ Florence Sylvestre, ' Florence Ruaudel, ${ }^{2}$ Edward J \\ Anthony ${ }^{1,3}$ and Cécile Miramont ${ }^{2}$
}

\begin{abstract}
Sediments from Lake Petit ( $2200 \mathrm{~m}$ a.s.l., Southern Alps) are particularly relevant for analysis of coupled landscape palaeoecology and palaeolimnology. Diatom assemblages, organic matter composition of sediments (total nitrogen and organic carbon) and Pediastrum boryanum concentrations were obtained from a I44-cm-long core, enabling the reconstruction of the aquatic ecosystem over nearly the last 5000 cal. BP. From 4800 to 4300 cal. BP, Lake Petit was a stable diatom-productive water body dominated by alkaliphilous diatoms (Staurosirella pinnata). During this period, nutrients and cations were supplied by the chemical weathering of podzols that developed under conifer woodlands. This overall stability was suddenly interrupted at 4200 cal. BP by a major detrital pulse that was probably climate linked (4200 cal. BP event) and that triggered a drop in diatom productivity and diversity. From 4 I 00 to 2400 cal. BP, diatom productivity progressively decreased, whereas Pediastrum developed. Diatom assemblages were more diversified (predominance of Pseudostaurosira robusta, P. brevistriata and P. pseudoconstruens) and reflected a regime of continuous erosion, whereas slopes were colonised by grazed grasslands. Finally, from $2400 \mathrm{cal}$. BP to the present day, diatom assemblages reveal a slight acidification and nutrient enrichment of waters concomitant with increasing human pressure in the catchment. These results demonstrate the close links between ecosystems and the ready propagation of disturbances throughout watersheds that might lead to abrupt regime shifts in such alpine environments.
\end{abstract}

\section{Keywords}

alpine lake, catchment-lake interaction, diatoms, Holocene, reference conditions, $4200 \mathrm{cal}$. BP event

\section{Introduction}

Determining baseline conditions for freshwater ecosystems is of crucial interest for wildlife conservation. The European Union Water Framework Directive has undertaken actions aimed at restoring a 'good ecological status' in all water bodies, raising the tricky question of the identification of target conditions for restoration (Bennion and Battarbee, 2007; Bennion et al., 2011). These reference conditions may be defined with regard to 'deviation' from 'pre-anthropogenic' conditions of species communities, ecosystem productivity and physico-chemical parameters, but they usually rely on instrumental data and short-term studies covering less than the last two centuries (Battarbee et al., 2011; Bennion and Simpson, 2011; Guilizzoni et al., 2011). However, it is now well known that environments have been deeply impacted by human activities at least at the millennial timescale (Berglund, 2011). Lastly, the definition of a single limit for anthropogenic imprint in the Holocene history of environments remains debatable since human activities and impacts might have occurred asynchronously between sites (Balter, 2013; Steffen et al., 2011).

Beyond the definition of a pre-anthropogenic state, palaeolimnological studies represent a valuable means of obtaining long-term insight into the mechanisms that lead to present day ecosystems (Bennion et al., 2011; Smol, 1992) and into the boundary conditions within which an ecosystem may change (Battarbee et al., 2005). Multi-proxy investigations on lake sediments enable tracking back the dynamics of lacustrine and local vegetation ecosystems over millennia as well as their response to human impact and climate change (Birks and Birks, 2006; Dearing, 2013; Randsalu-Wendrup et al., 2014). Such external forcing may lead to a variety of lake responses, ranging from gradual changes to sudden and drastic switches (Carstensen et al., 2013; Scheffer et al., 1993; Scheffer et al., 2001; Wang et al., 2012), depending on the characteristics of the terrestrial and lacustrine ecosystem. In this context,

\footnotetext{
'Aix-Marseille University, CNRS, IRD, Collège de France, UM 34 CEREGE, France

${ }^{2}$ Aix-Marseille University, CNRS, IRD, Avignon University, UMR 7263 IMBE, France

Institut Universitaire de France, France
}

\section{Corresponding author:}

Rosine Cartier, CNRS, IRD, Collège de France, UM 34 CEREGE, Aix-Marseille University, Technopôle de l'Arbois BP 80, 13545 Aix-enProvence cedex 04, France. Email: cartier@cerege.fr 

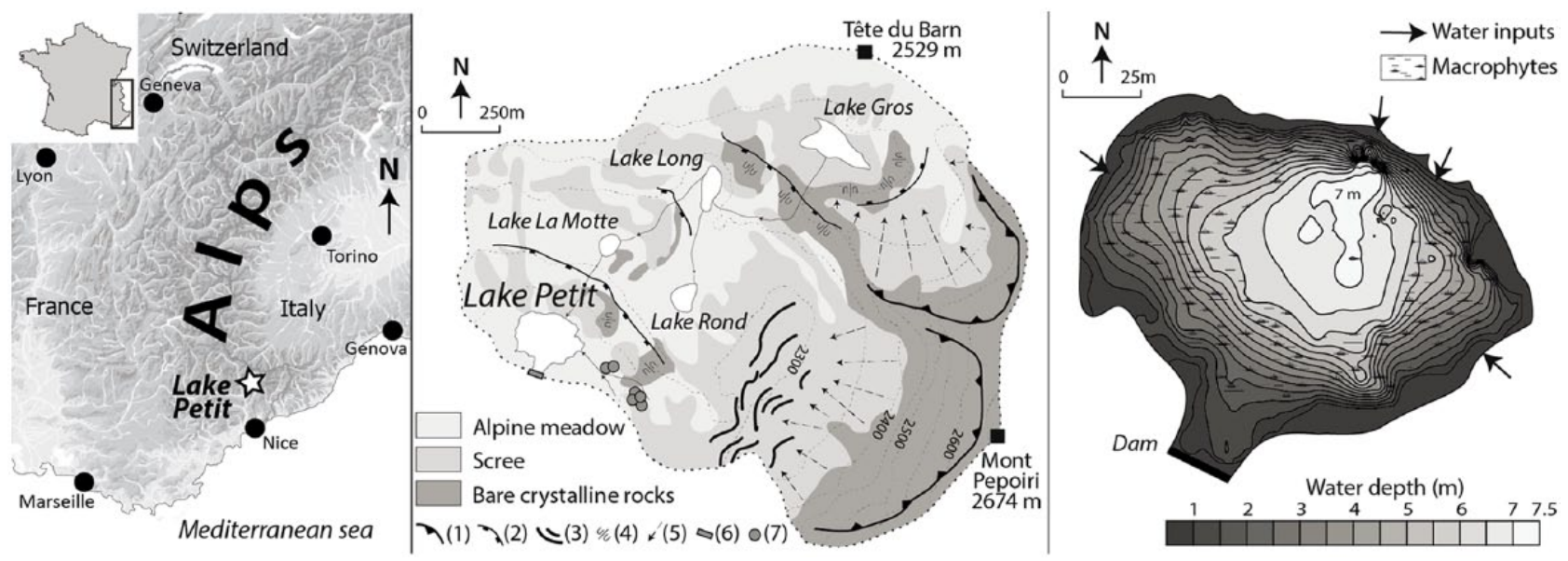

Figure I. Location map of the study site and main geomorphological characteristics of the catchment and bathymetry of Lake Petit. I: glacial cirque; 2: glacial step; 3: moraine; 4: polished bedrock; 5: active debris slope; 6: small dam built in 1947; 7: ancient pastoral enclosures (Suméra et al., 2008).

understanding long-term coupled lake-landscape interactions is decisive in distinguishing factors that trigger lake trajectories (Fritz, 2008; Lotter and Birks, 2003). Regarding such coupled relationships, palaeolimnological studies, based, in particular, on diatom analysis, can provide powerful results on reconstructed hydrochemical variations (Alefs and Müller, 1999; Schmidt et al., 2004). Diatom species are closely related to environmental parameters and respond quickly to ecological perturbations (Bigler et al., 2006; Dam et al., 1994; Smol and Stoermer, 2010).

Alpine lakes are a prime source of insight into long-term lake trajectories because they are relatively simple systems characterised by short aquatic trophic chains and small hydrographical networks. Moreover, these systems are commonly exposed to extreme environmental conditions (Beniston, 2003, 2006), an annually long period of ice cover, persistence of low temperatures and low nutrient availability, all of which render their aquatic communities particularly sensitive to landscape and climatic changes (Druart et al., 1999; Quesada et al., 2006; Rühland et al., 2008). In these lakes, changes in air temperature, precipitation and wind regime can lead to profound hydrological and physicochemical perturbations (Battarbee et al., 2002; Lotter et al., 1997; Sommaruga-Wögrath et al., 1997; Thompson et al., 2005). Mountain-related anthropogenic activities are also a potential source of disturbance of lacustrine ecosystems mainly through changes in nutrient inputs and light availability (Heiri and Lotter, 2003; Lotter and Birks, 2003). In the Southern Alps, human presence is ancient and has been dated by archaeological and charcoal studies from the Bronze Age (ca. 5000-4000 cal. BP; De Lumley and Echassoux, 2009; Walsh et al., 2007) onwards. Forest clearance linked to increasing pastoralism since ca. $3000 \mathrm{cal}$. BP has been evidenced (De Beaulieu, 1977; Finsinger, 2001; Ortu et al., 2003; Ponel et al., 2011; Walsh et al., 2007). However, few palaeoenvironmental studies have been carried out on the responses to longterm forcing of lakes in the Southern Alps (Gandouin and Franquet, 2002; Larocque and Finsinger, 2008), which differ from those in the Northern Alps in terms, notably because of the Mediterranean climatic influence to which the former are subject.

Sediments from Lake Petit $(2200 \mathrm{~m}$ a.s.l., Southern French Alps) have turned out to be particularly relevant in a spate of recent studies on the coupling of landscape palaeoecology and palaeolimnology. This relevance stems from (1) exceptional richness in preserved bio-indicators, especially algae (diatoms and Pediastrum); (2) a well-constrained archaeological context (Morin and Rosenthal, 2002; Pagès, 2009; Suméra et al., 2008); and (3) an identified tipping point in the terrestrial ecosystem history at 4200 cal. BP from multi-proxy studies of the ambient vegetation and soil dynamics (Brisset et al., 2013). This paper focuses essentially on the lacustrine ecosystem, complementing these previous studies.

By coupling palaeoecological analysis (counting of diatoms and Pediastrum algae) and geochemical measurements (carbon, nitrogen and biogenic silica), backed by the palaeoenvironmental studies of Brisset et al. (2012, 2013), this paper aims at (1) reconstructing changes in the lacustrine ecosystem of Lake Petit over the last 4800 years, (2) analysing relationships between the lacustrine and ambient terrestrial ecosystems, particularly through the effect of soil erosion on lacustrine nutrient input, (3) disentangling the influence of human impact and climate variability and (4) evaluating the resilience of the lacustrine ecosystem following perturbations.

\section{Study site}

\section{Setting}

Lake Petit $\left(2200 \mathrm{~m}\right.$ a.s.1.; $\left.44^{\circ} 06^{\prime} 789^{\prime \prime} \mathrm{N} ; 7^{\circ} 11^{\prime} 342^{\prime \prime} \mathrm{E}\right)$ is a small circular body of water $150 \mathrm{~m}$ in diameter located in the Southern French Alps about $60 \mathrm{~km}$ from the Mediterranean Sea and is the lowest in elevation of a chain of five lakes partly inherited from glacier retreat (Figure 1). The lakes are connected in spring by ice meltwater but remain unconnected the rest of the year. The lake catchment (area: $6 \mathrm{~km}^{2}$ ), culminating at $2600 \mathrm{~m}$ a.s.1., is composed of crystalline bedrock (gneiss and migmatites) and is largely covered by alpine meadows; the upper treeline (Larix sp.) is located at about $2100 \mathrm{~m}$ a.s.1. Macrophyte vegetation composed of Ranunculus aquatilis colonises the fringes of the lake (Figure 1). The lake surface is usually frozen from October to April. The depth of Lake Petit is up to $7 \mathrm{~m}$ in the wake of snow-melt in late spring and decreases to $6.5 \mathrm{~m}$ at the end of summer. During summer, continuous water inflow is assured by further melting of residual snow trapped in surrounding moraine and scree. The mean lake-level has been artificially raised by about $1.5 \mathrm{~m}$ by the construction of a small dam in 1947 (Beniamino, 2006). This dam is now in ruins, allowing for a nearly permanent water outflow. Measurements of the physico-chemical properties of the lake waters were conducted in spring (17 May 2012). These waters are characterised by $66 \%$ of oxygen saturation, a $\mathrm{pH}$ of 8 (at a water temperature of $\left.7^{\circ} \mathrm{C}\right)$ and are rich in calcium $\left(\left[\mathrm{Ca}^{2+}\right]=14.1 \pm 0.3 \mathrm{mg} / \mathrm{L}\right)$, sulphates $\left(\left[\mathrm{SO}_{4}^{2-}\right]=5.2 \pm 0.1 \mathrm{mg} / \mathrm{L}\right)$ and silica $\left(\left[\mathrm{Si}^{4+}\right]=2.7 \pm 0.1 \mathrm{mg} / \mathrm{L}\right)$. 
Phosphates were absent $\left(\left[\mathrm{PO}_{4}^{3-}\right]<0.03 \mathrm{mg} / \mathrm{L}\right)$. The measured nitrate concentration $\left(\mathrm{NO}_{3}^{-}\right)$was $0.07 \pm 0.01 \mathrm{mg} / \mathrm{L}$.

Alpine and Mediterranean influences generate a climate marked by mild winters and dry summers. Mean annual temperature at $1800 \mathrm{~m}$ a.s.1. is $5^{\circ} \mathrm{C}$, varying from $0.3^{\circ} \mathrm{C}$ in winter to $9.9^{\circ} \mathrm{C}$ in summer (Durand et al., 2009), with rainfall occurring mainly in spring and autumn. Mean annual precipitation is $1340 \mathrm{~mm}$ at $1800 \mathrm{~m}$ a.s.l. Snow depths in winter are relatively important (150$250 \mathrm{~cm}$ at $2400 \mathrm{~m}$ a.s.1.) due to moisture from the nearby Mediterranean sea. Snow cover duration is about 185 days at $2100 \mathrm{~m}$ a.s. 1 . (Durand et al., 2009).

\section{Previous multidisciplinary studies}

Sediments of Lake Petit have been previously studied, allowing for a detailed reconstruction of the past terrestrial environment through combined sedimentological, geochemical and palynological approaches (Brisset et al., 2012, 2013). These studies highlighted the prevalence of complex interactions between vegetation and pedogenetic processes in the lake catchment over the last five millennia. The results show, from 4800 to $4200 \mathrm{cal}$. BP, a progressive development of podzols under coniferous forest conditions and overall slope stability. Degradation of podzols occurred abruptly at 4200 cal. BP, marked by a major detrital pulse in the lake sediment archives. Since 4200 cal. BP, moderately weathered cambisols and alpine meadows associated with ruderal-anthropogenic plants in the catchment have constituted a stable state characterised by uninterrupted terrigenous inputs into the lake.

Archaeological investigations in the catchment have also evidenced the presence of (1) 30 pastoral enclosures, mainly dating to the late Middle Ages (1000-600 cal. BP), but one of which, located upstream of the lake, has been dated from 2140 to 2000 cal. BP (Suméra et al., 2008; Figure 1) and (2) several sites of iron ore extraction and smelting that were in activity from 2200 to 1600 cal. BP (Morin and Rosenthal, 2002; Pagès, 2009). The presence of livestock is abundantly attested between 1300 and 400 cal. BP.

\section{Materials and methods}

Sediment cores were taken in 2009 (PET09P2) and 2012 (PET12P3) in the deepest part of the lake using a UWITEC gravity corer. Correlations between core PET09P2 (144 cm long) and core PET12P3 (75 cm long) are based on lithological markers (colour and texture). Sediments are composed of homogenous yellow to greenish diatomite with millimetre-thick diffuse brownish diatomite-clay laminations. Sedimentological (dry density); geochemical (biogenic silica, carbon and nitrogen); and radiochronological analyses, as well as Pediastrum counts (identified during pollen analysis), were carried out on core PET09P2. The age-depth model is based on short-lived ${ }^{210} \mathrm{~Pb}$ and ${ }^{137} \mathrm{Cs}$ radionuclides and seven ${ }^{14} \mathrm{C}$ ages obtained from terrestrial macro-remains (see Supplementary Material 1, available online, and Brisset et al. (2013) for further details). This study was conducted on core PET09P2, which covers the last $4800 \mathrm{cal}$. BP, complemented by some samples from core PET12P3.

\section{Diatom and Pediastrum analyses}

Diatom analyses were conducted on 45 samples in PET09P2. In order to improve resolution for the uppermost $30 \mathrm{~cm}$, we analysed a further eight samples from core PET12P3. A total of 53 diatom samples $\left(1 \mathrm{~cm}^{3}\right)$ were taken in both cores and weighed after drying at $50^{\circ} \mathrm{C}$ (Supplementary Material 1, available online). Diatom taxonomic and counting analyses were conducted on $0.3 \mathrm{~g}$ samples and treated using standard procedures (1:1 mixture of
$\mathrm{H}_{2} \mathrm{O}_{2}$ :water, 1:1 mixture of $\mathrm{HCl}$ :water and repeatedly rinsed in distilled water; slides were made using Naphrax). For each sample, at least 400 diatom valves were identified and counted using a Nikon Eclipse 80i light microscope (differential interference contrast optics, $1000 \times$ magnification, numerical aperture $(\mathrm{NA})=1.25$ ). Diatom valves were counted in 10 randomly chosen fields to calculate diatom concentrations (number/g dry sediment).

Specimens were identified to their lowest taxonomic level (e.g. variety) following the species concept of Krammer and Lange-Bertalot (1986-1991). Several identified genera and species have been re-assessed using the classification by Round et al. (1990), and synonyms were introduced. Diatom identification was also based on Marciniak (1988 [1986]) and Fallu et al. (2000).

The diatom species percentage diagram was plotted using C2 software (Juggins, 2007). Diatom assemblage zones (DAZs) were defined according to a constrained hierarchical clustering using the CONISS algorithm (Grimm, 1987). The number of significant zones was determined using the 'broken-stick' model (Bennett, 1996) based on the R package 'rioja' (Juggins, 2012). Diatoms were also classified into ecological groups according to their specific preferences in $\mathrm{pH}$ and their trophic requirements (Krammer and Lange-Bertalot, 1986-1991; Dam et al., 1994). Species diversity was estimated through species richness and equitability calculated using the Shannon diversity index as follows:

$$
\operatorname{Equitability}(E)=\frac{\text { Shannon diversityindex }(H)}{\ln (\text { species richness }(S))}
$$

In order to compare species richness for samples of different counting sizes, the count sums were standardised using rarefaction analysis (Birks and Line, 1992). Expected species richness $E(S n)$ was calculated using the R package vegan (Oksanen et al., 2007 , retaining a common count sum of $\left.400\left(\mathrm{E}_{\mathrm{S} 400}\right)\right)$.

Pediastrum coenobia were extracted from sediments following Bennett (1990) and were identified following Komárek and Jankovská (2001) in 144 samples collected in constant volume $\left(1 \mathrm{~cm}^{3}\right)$ at each centimetre of core PET09P2. Pediastrum concentrations were expressed in number per millilitre.

\section{C, $N$ analysis, biogenic silica fluxes and PCA ordination}

Analysis of total carbon (TC) and total nitrogen (TN) in the sediment was conducted on 50 samples. The percentages of TC and TN of each $10 \mathrm{mg}$ of dry sediment sample (after crushing and conditioning into tin capsules) were measured by gas chromatography using a FLASH 2000 series Thermo Fisher. Percentages of TC correspond to total organic carbon (TOC) since inorganic carbon is totally absent in the sedimentary record (Brisset et al., 2013). Differences in TOC/TN ratios (abbreviated as $\mathrm{C} / \mathrm{N}$ ratio), expressed as atomic or weight ratios, can be interpreted as changes in the relative contribution of terrigenous and lacustrine organic matter (Meyers and Teranes, 2001).

Diatoms (D) represent the major compound of biogenic silica in the sedimentary record. Only few cysts of Chrysophyceae (C) were identified during counting $(\mathrm{C} / \mathrm{D}$ rate $=0.01)$. Biogenic silica $(\%)$ was calculated at high resolution $(0.2 \mathrm{~cm})$ by Fourier transform infrared spectroscopy (FTIR) and calibrated with measures of wet-alkaline leaching on 28 discrete samples (see details in Brisset et al., 2013). Diatom productivity can be estimated through biogenic silica fluxes $\left(\mathrm{SiO}_{2 \mathrm{biog}}\right.$ flux) calculated as follows:

$$
\begin{aligned}
& \operatorname{SiO}_{2 \text { biog }} \text { flux }\left(\mathrm{g} / \mathrm{cm}^{2} / \mathrm{yr}\right)=\operatorname{drydensity~}\left(\mathrm{g} / \mathrm{cm}^{3}\right) \times \\
& \text { sedimentation rate }(\mathrm{cm} / \mathrm{yr}) \times \% \mathrm{SiO}_{2 \text { biog }}
\end{aligned}
$$


Finally, we used principal components analysis (PCA) to evidence, through time, interactions between aquatic communities (diatom species composition, Pediastrum concentrations) and organic matter composition (TOC, TN and $\mathrm{C} / \mathrm{N}$ ratios). For the PCA ordination, 14 dominant diatom species having a relative abundance higher than $5 \%$ in the assemblages were selected. The abundance of the detrital fraction (DF) within bulk sediment (\% dry mass DF) was integrated in the PCA as a variable representative of soil erosion. The DF represents the addition of major detrital elements (for more details, see Brisset et al., 2013). The 3-cm running mean concentrations (number $/ \mathrm{cm}^{3}$ ) of Pediastrum were calculated to smooth out high-frequency variability.

\section{Results}

\section{Diatom species composition and Pediastrum}

A total of 39 genera and 111 taxa were identified. Only species with a relative abundance of $>2 \%$ are shown in the simplified diagram in Figure 2. Diatom assemblages over the last five millennia are mainly dominated by species of Fragilariaceae. From the base of the core $(144 \mathrm{~cm})$ to $105 \mathrm{~cm}, \mathrm{DAZ}_{-} 1$ is strongly dominated by Staurosirella pinnata, which represents, on average, $74 \%$ of total diatoms. From 144 to $116 \mathrm{~cm}$, this species is associated with Pseudostaurosira robusta, which punctually peaks at 25\%, Pseudostaurosira pseudoconstruens, Encyonema minutum and Pseudostaurosira brevistriata. From 116 to $105 \mathrm{~cm}$, these species virtually disappear, and $S$. pinnata becomes very largely dominant, reaching $90 \%$ of the total assemblage. From $105 \mathrm{~cm}$ to the top of the core, DAZ_2 exhibits an abrupt decline in S. pinnata, replaced by P. robusta. DAZ_2 can be further subdivided into three sub-units according to diatom species composition. DAZ_2a $(105-66 \mathrm{~cm})$ is characterised by important concentrations of $P$. robusta, P. brevistriata, P. pseudoconstruens and Staurosirella lapponica. S. lapponica then progressively decreases in this unit. DAZ_2b $(66-22 \mathrm{~cm})$ is defined by a decline in $P$. robusta, whereas $P$. pseudoconstruens, E. minutum, Sellaphora pupula, Staurosira construens var.venter, Navicula radiosa, Amphora libyca and Achnanthes oestrupii increase. Finally, DAZ 2c $(22-0 \mathrm{~cm})$ is characterised by $S$. pinnata, whereas $P$. robusta decreases to $20 \%$. P. pseudoconstruens, $P$. microstriata, $S$. construens var. venter and Opephora mutabilis are also associated with $S$. pinnata in DAZ_2c.

Pediastrum remains have been identified as P. boryanum var. forcipatum. The mean Pediastrum concentration along the core is $1307 \mathrm{nb} / \mathrm{mL}$. The peak concentration is $3700 \mathrm{nb} / \mathrm{mL}$ at $100 \mathrm{~cm}$ depth. Mean Pediastrum concentration is $810 \mathrm{nb} / \mathrm{mL}$ in DAZ_1 and $1450 \mathrm{nb} / \mathrm{mL}$ in DAZ_2 (Figure 2).

\section{Diatom ecological affinities and diversity}

Diatom assemblages are composed of benthic organisms living fixed to different supports (Figure 2). Fragilariaceae are usually considered to be broadly benthic, with the capacity of thriving in the water column during re-suspension of superficial sediment. The dominant species identified in this record (e.g. Staurosirella pinnata, Pseudostaurosira robusta, Pseudostaurosira pseudoconstruens and Pseudostaurosira brevistriata) are typical of alkaliphilous and oligotrophic environments but are tolerant of trophic variations (Figure 3).

DAZ_1 is dominated by tychoplanktonic and alkaliphilous species (e.g. S. pinnata). Epipelic diatoms (that can grow on mud) represented by $S$. lapponica, $S$. pupula and A. libyca increase in DAZ_2a. Fragilariaceae decreases at the beginning of DAZ_2b while meso-eutrophic (e.g. S. pupula, N. radiosa and S. construens var. venter) and circumneutral species (e.g. E. minutum, A. libyca and $S$. pupula) increase and peak at about $10 \%$ of total diatoms. Epilithic and epiphytic diatoms (e.g. Cymbella spp., Encyonema spp. and Gomphonema spp.), living fixed on macrophytes and rocks, increase in this unit and in DAZ_2c (mean value of $6.3 \%$ ). These results suggest changes in $\mathrm{pH}$, nutrient enrichment and habitat availability for diatom species throughout the record.

Diatom diversity was estimated by expected diatom richness (not shown) and equitability (Figure 3). Expected species richness values range from 17 to 54 and equitability values from 0.16 to 0.75. In DAZ_1, assemblages are poorly diversified (dominated by $S$. pinnata), and the lowest equitability values (less than 0.2 ) occur from 115 to $105 \mathrm{~cm}$. DAZ_2a is characterised by an important development of $P$. robusta, $\bar{P}$. brevistriata, P. pseudoconstruens and Staurosirella lapponica, which entail an increase in diversity (equitability $>0.5$ ). Finally, equitability peaks at 0.8 in DAZ_2b and DAZ_2c.

\section{C, $N$ analysis, biogenic silica fluxes and valve concentrations}

TOC values range from $16 \%$ to $6 \%$ (Figure 3). From 144 to $115 \mathrm{~cm}$, values of TOC attain a maximum of ca. 13\%. From 115 to $107 \mathrm{~cm}$, the TOC curve decreases abruptly to the lowest value $(6 \%)$. From 107 to $0 \mathrm{~cm}$, TOC values are about $8 \%$ except between 65 and $25 \mathrm{~cm}$ where values sporadically peak to $10 \%$. Mean TN is $0.9 \%$. From 144 to $107 \mathrm{~cm}$, TOC and TN are covariant. In the upper part of the core, TN is maximal between 70 and $25 \mathrm{~cm}(\sim 0.4 \%)$. Mean $\mathrm{C} / \mathrm{N}$ is 11.5 from 144 to $107 \mathrm{~cm}$ and 9.2 from 107 to $0 \mathrm{~cm}$. Maximal biogenic silica values occur from 144 to $120 \mathrm{~cm}(0.15 \mathrm{~g} / \mathrm{cm} 2 / \mathrm{yr}$; Figure 3$)$. Biogenic silica flux decreases to a minimum at $110 \mathrm{~cm}(0.05 \mathrm{~g} / \mathrm{cm} 2 / \mathrm{yr})$ and values remain low in DAZ_2, except from 50 to $40 \mathrm{~cm}$ and in the upper $5 \mathrm{~cm}$. Valve concentrations range from 1.27 to $11.3 \times 10^{9}$ valves $/ \mathrm{g}$ dry sediment (Figure 3). Mean concentrations in DAZ_1 are $7.9 \times 10^{9}$ valves/g of dry sediment and $3.5 \times 10^{9}$ valves/g of dry sediment in DAZ_2. Concentration peaks at $11.3 \times 10^{9}$ valves $/ g$ dry sediment at $3 \overline{\mathrm{cm}}$ depth.

\section{PCA ordination and multi-proxy zonation}

The total percentage of variation explained by the first two principal components (PC1 and PC2) is 38\%, with eigenvalues of $\lambda_{1}=0.23$ and $\lambda_{2}=0.15$, respectively (Figure 4). Variables TOC, $\mathrm{C} / \mathrm{N}$ and $S$. pinnata are strongly positively correlated with PC1, whereas $P$. robusta, A. oestrupii, S. pupula, P. pseudoconstruens and Pediastrum are the most negatively correlated with PC1 $(p<0.01)$. PC1 separates samples up to and after 4100 cal. BP (corresponding to the limit between DAZ_1 and DAZ 2). Variables positively correlated with PC2 are TN, TOC, $A$. libyca, $N$. radiosa, E. minutum, $S$. pupula, $P$. brevistriata var. papillosa and $P$. brevistriata. The DF variable is negatively correlated with PC2 $(p<0.01)$. The strongest negative weight of DF is between 120 and $105 \mathrm{~cm}$ and from 25 to $0 \mathrm{~cm}$. Accordingly, five zones corresponding to the time periods delineating the palaeoenvironmental history of Lake Petit have been defined as follows: 4800-4300, $4300-4100,4100-2400,2400-800 \mathrm{cal}$. BP and from $800 \mathrm{cal}$. BP to the present.

\section{Palaeoenvironmental history}

Over the last 4800 years, Lake Petit has been dominated by small tychoplanktonic alkaliphilous Fragilariaceae. This group comprises taxa having a wide range of ecological tolerances. They can be found as pioneer assemblages in lagoons progressively isolated from the sea (Stabell, 1985) as well as in new lakes following the retreat of glaciers (Haworth, 1976), in contexts marked by rapid 


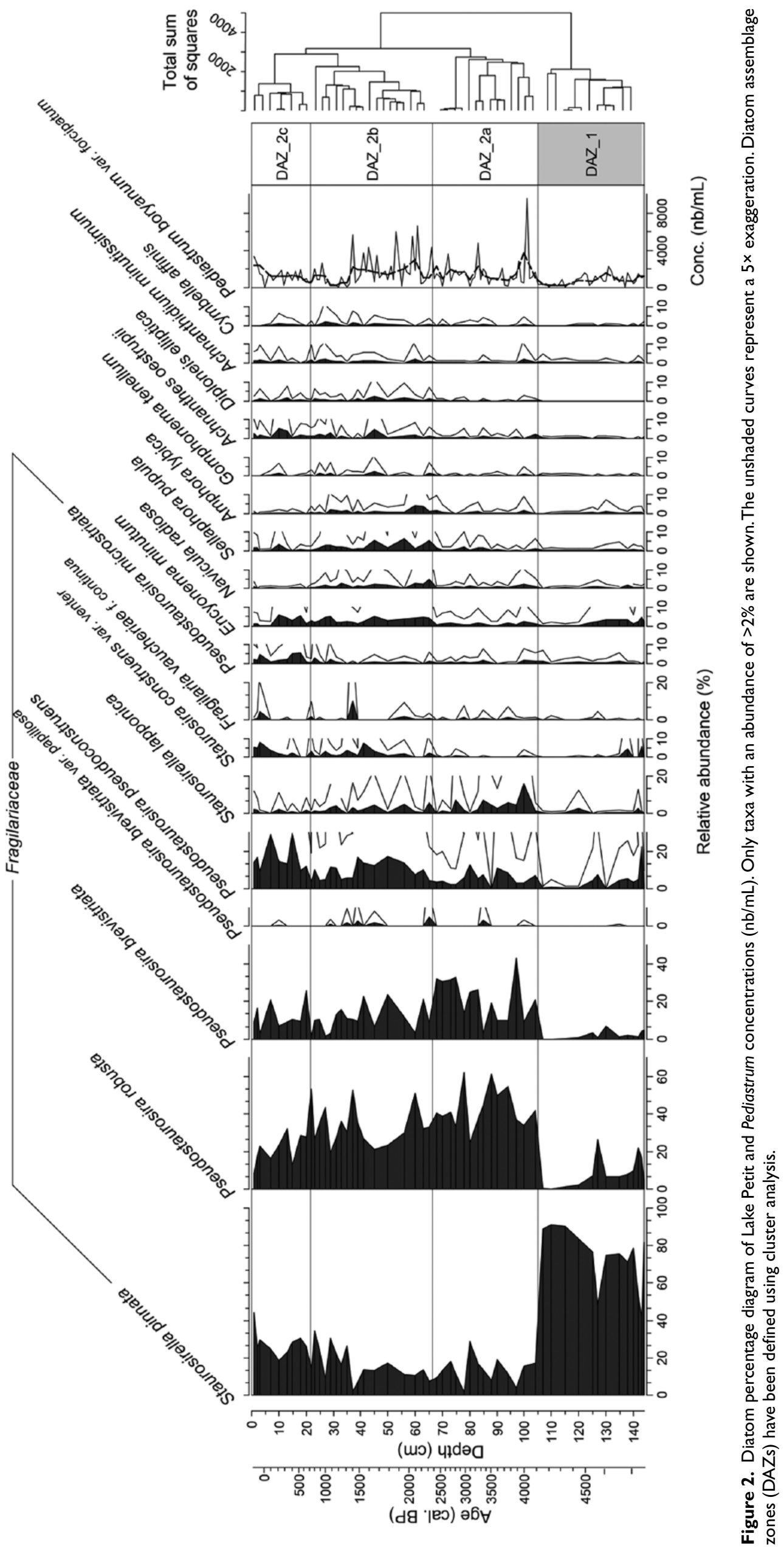




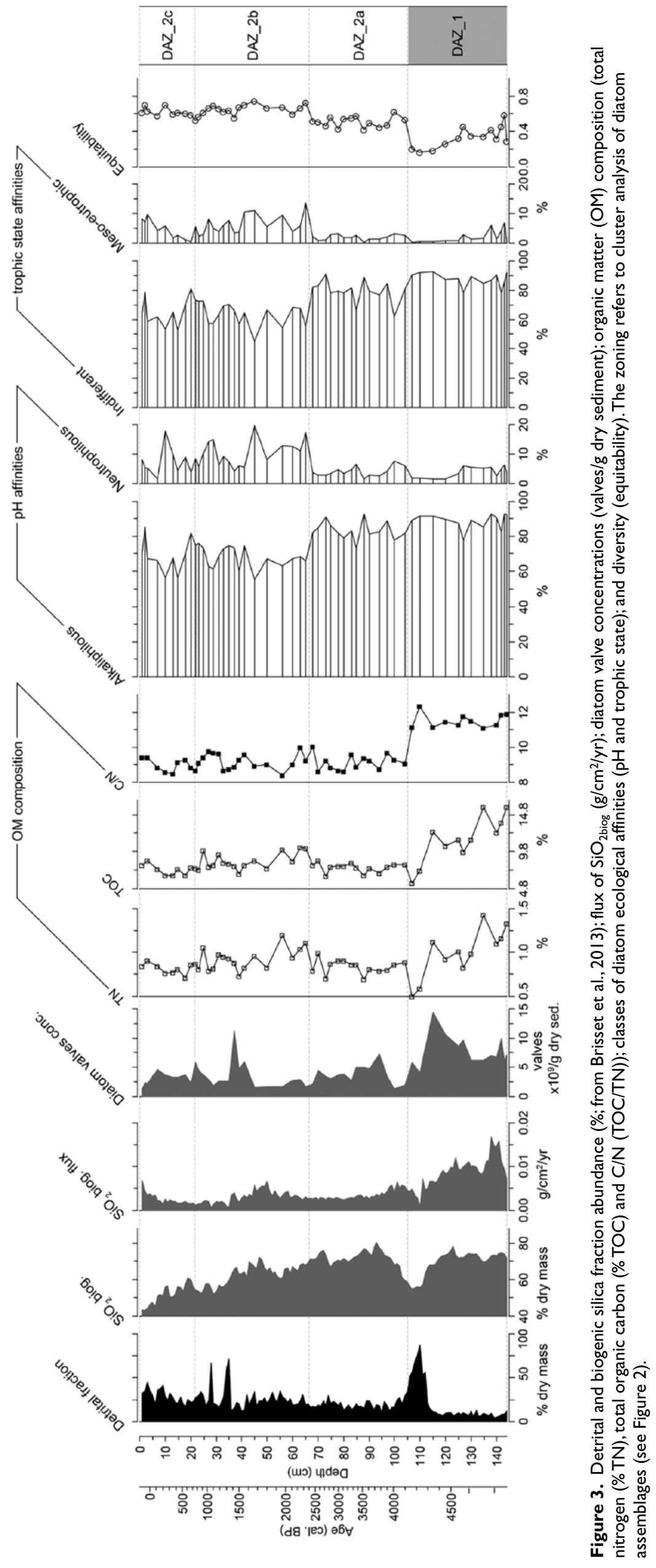




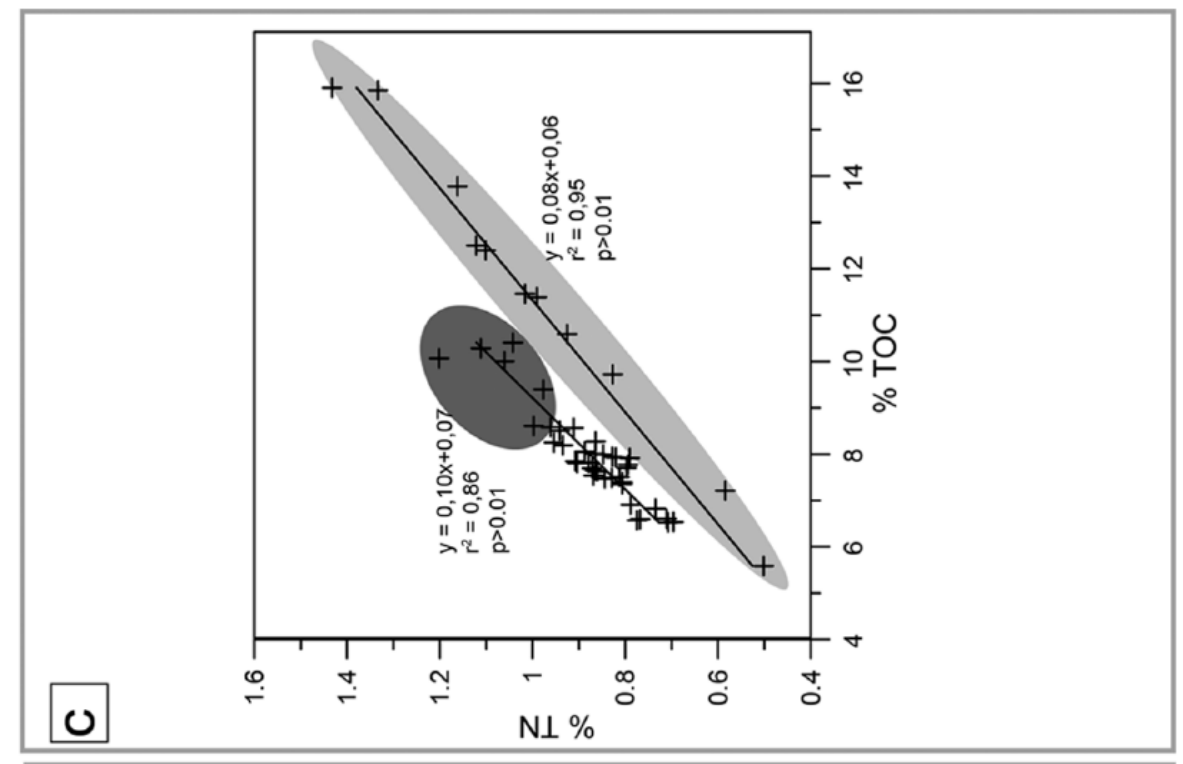

Uิ

踤立这 U.

论 胥

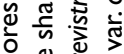

पूँ ปे

อิ yूd

ปิ่

욜

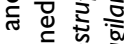

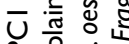

文告

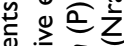

임

ํํㅇำ

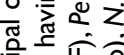

웧웡

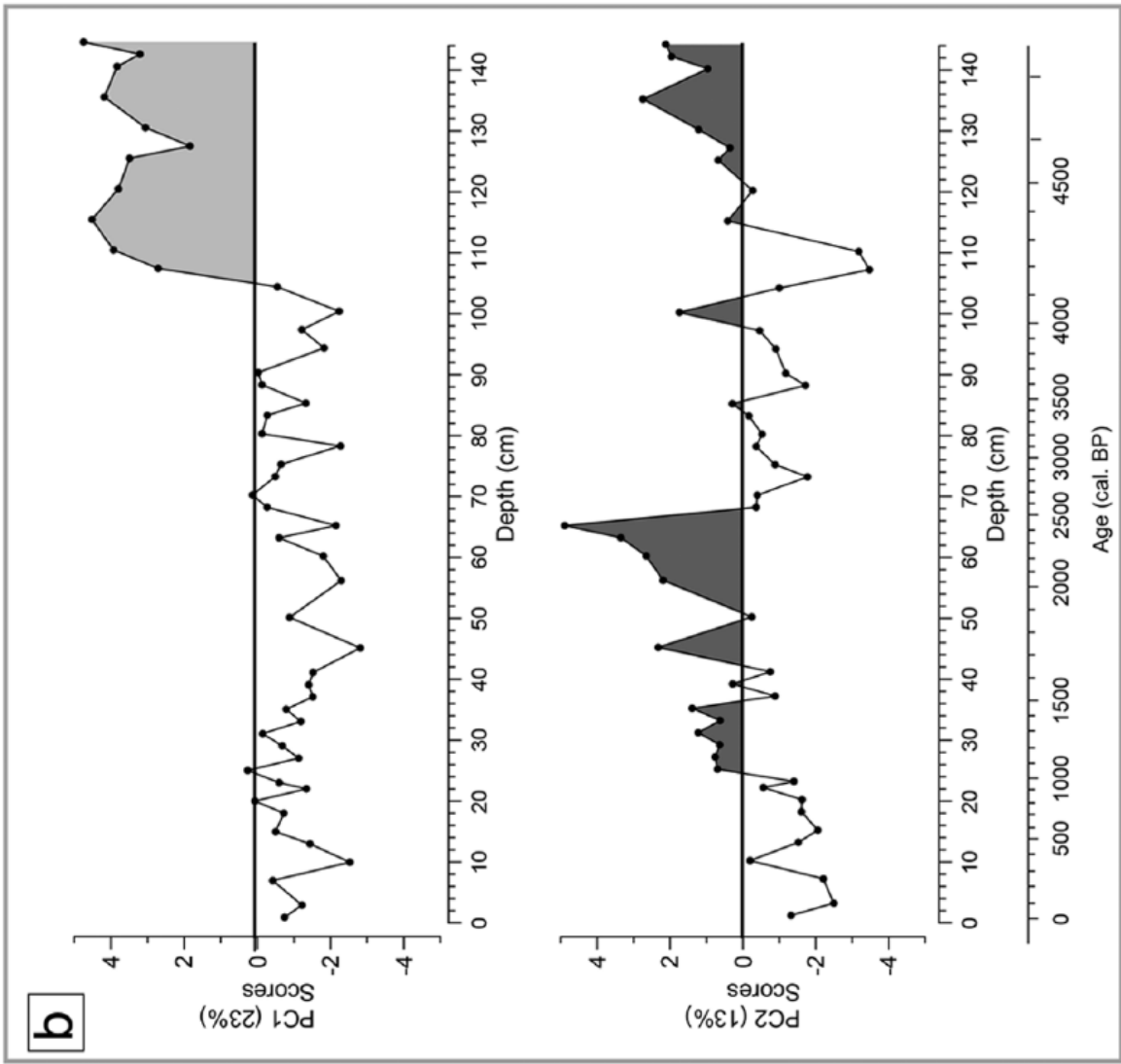

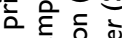

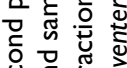

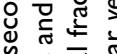

包.

ฮ $\frac{0}{2}$

紊六

过

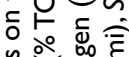

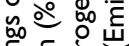

음 은

은 퓬

ป ญे है

ㅇํㅇ ㅇํㅇ

ฮิ ठำ

نั

은 는

劳焉的

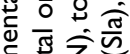

원.

.

ฮ

跣莫 v

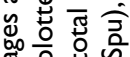

है $\widehat{\bar{U}} \div$

ปั

入든

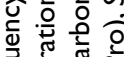

न 원

넌

ธิ ป็

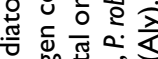

प

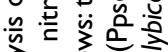

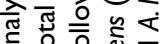

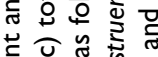

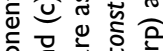

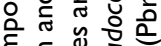

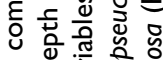

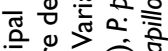

就宂

จ 0 은

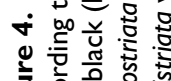

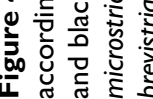




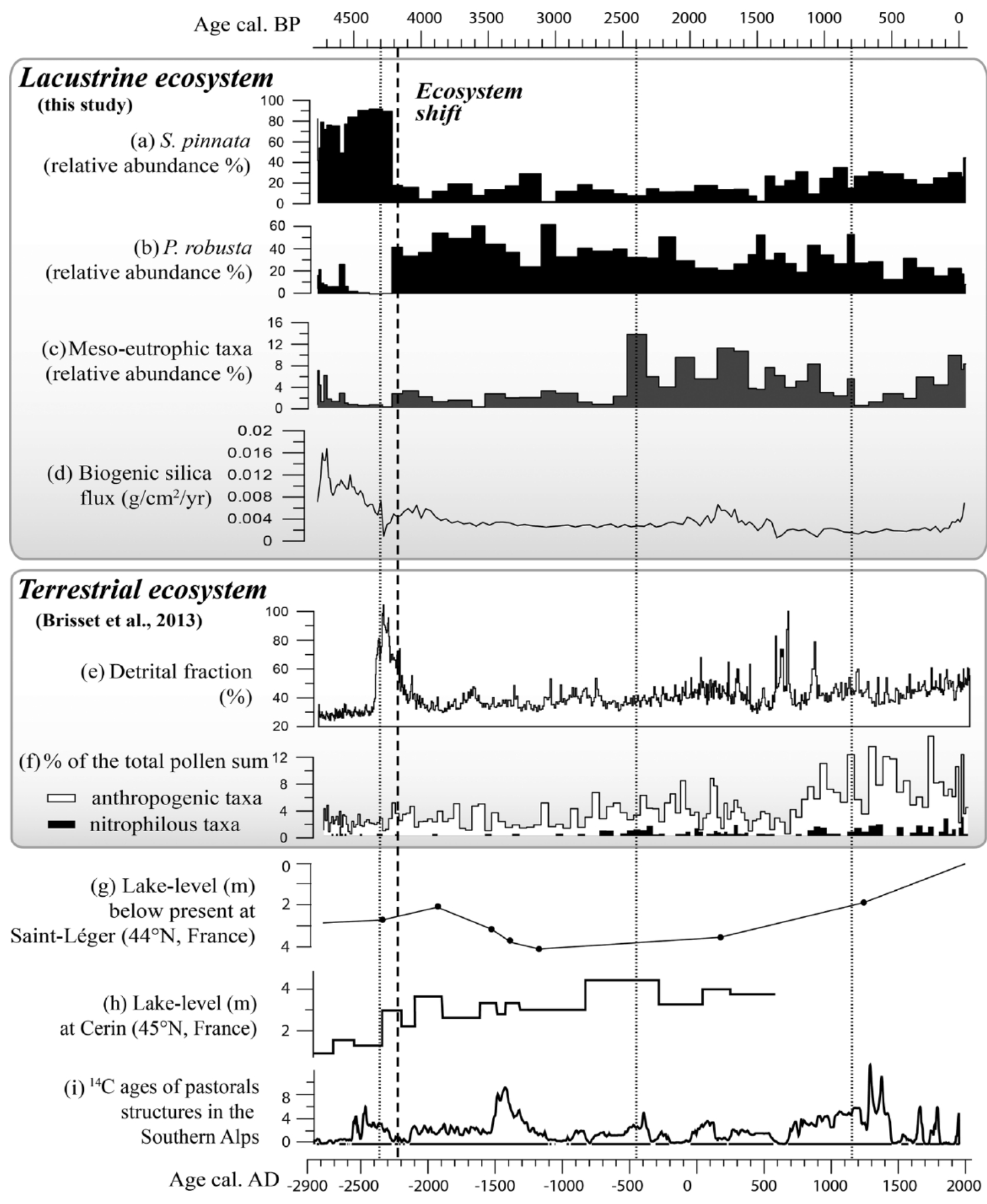

Figure 5. Lacustrine ((a)\% S. pinnata, (b) \% P. robusta, (c) \% meso-eutrophic diatoms and (d) biogenic silica flux; this study) and terrestrial ((e) $\%$ detrital fraction, (f) \% pollen; Brisset et al., 20I3) ecosystem proxies compared to hydrological conditions at (g) Lake Saint-Léger (Digerfeldt et al., 1997), (h) Lake Cerin (Magny et al., 20I2a) and (i) number of ${ }^{14} \mathrm{C}$ dates $(2 \sigma)$ of pastorals structures in archaeological stratigraphies in the Southern Alps (Walsh et al., 2007).

changes in physico-chemical conditions. Fragilariaceae can also be abundant in nutrient-rich lakes (Bennion et al., 2001) and in cold, nutrient-poor high mountain lakes with short growing seasons (Catalan et al., 2002; Wögrath and Psenner, 1995). This family is commonly observed in alpine (e.g. Hustedt, 1943; Lotter et al., 1999; Schmidt et al., 2004), arctic and subarctic lakes (e.g. Pienitz et al., 1995; Smol, 1988; Westover et al., 2006). At the species level, differences have also been found in these taxa in response to environmental change, and Fragilariaceae have revealed a good potential for palaeoenvironmental studies (Finkelstein and Gajewski, 2008; Schmidt et al., 2004). These observations are confirmed by the record from Lake Petit where species of Fragilariaceae (and other sub-dominant taxa) highlight a major shift that undoubtedly represents a significant change in the lacustrine ecosystem. 


\section{From 4800 to $4300 \mathrm{cal}$. BP:A long-lasting lake- catchment equilibrium}

Maximal values of biogenic silica flux and concentrations indicate that a major part of the sedimentation was assured by the autochthonous production of diatoms. The high TN and TOC values suggest that organic matter is abundant during this period, and a mean $\mathrm{C} / \mathrm{N}$ ratio of 11.5 can be interpreted as a mixture of lacustrine algae and terrestrial vascular plants (Meyers and Teranes, 2001). Diatom assemblages are poorly diversified and dominated by $S$. pinnata (Figure 5a) typically observed in alkaline and welloxygenated lakes (Dam et al., 1994; Schmidt et al., 2004). Additionally during this period, (1) minerogenic inputs were low, (2) phosphorus $(\mathrm{P})$ and calcium were preferentially trapped in the lake and (3) the watershed was dominated by chemically weathered podzols under open mixed pine-larch woodlands (Brisset et al., 2013).

The concomitance of the maximal diatom flux with the preferential trapping of organic $\mathrm{C}, \mathrm{N}$ and $\mathrm{P}$ suggests that uptake of nutrients by diatoms was significant and stored via sedimentation processes. These nutrients are determinant in algal growth (Schindler et al., 2008; Vitousek and Howarth, 1991). The results regarding this period, thus, suggest that these nutrients were readily available in their soluble forms. Such nutrient supply might be linked with (1) leaching of dissolved minerals from soils (Filippelli et al., 2006; Likens et al., 1996; McLauchlan et al., 2013; Righi et al., 1999) and (2) terrestrial organic matter input from vegetation. Organic matter enrichment is susceptible to provide nutrients for primary producers through lake degradation processes (Vinebrooke and Leavitt, 1998).

This period is also dominated by alkaliphilous diatom species which might be surprising in crystalline catchments covered by acid soils that are more sensitive to water acidification (Reuss et al., 1987). However, as shown for a large set of Austrian alpine lakes, even in exclusively crystalline catchments, chemical weathering of developed soils might preserve lakes from acidification (Kamenik et al., 2001). Similar lake-catchment processes have been described by Schmidt et al. (2004) in a high-altitude lake of the eastern Alps (Oberer Landschitzsee, Austria), that is, a decrease in water $\mathrm{pH}$ throughout the Holocene (but remaining higher than 7) through long-lasting cation losses during progressive development of soil under pine wood cover.

Moreover, chemical weathering rather than particulate runoff in the watershed is likely to have favoured clear waters. Thus, pedogenetic processes might have played a major role in both promoting high diatom productivity and maintaining the alkalinity of water, which suggests a close interdependence of processes occurring on slopes and in the lake.

The period $4800-4300$ is also characterised by a relatively low diversity in diatom assemblages. The latter is highly dependent on habitat availability and on the frequency of ecological disturbances (Connell, 1978); therefore, a background of long-lasting favourable conditions may shape stable living aquatic communities comprising few species. In Lake Petit, the low diversity of diatom assemblages might be attributed to poor substrate heterogeneity for benthic diatoms in a context of very low environmental variability (in both frequency and intensity): thus, this relative stability supported the predominance of $S$. pinnata over the other diatom species.

\section{From 4300 to 4100 cal. BP:A switch to another ecosystem?}

During this period, the lacustrine ecosystem switches irreversibly from one of steady low diversity and high diatom production dominated by $S$. pinnata prior to 4300 cal. BP, to a new, low diatom-productive but diversified state dominated by $P$. robusta,
P. brevistriata and P. pseudoconstruens after 4100 cal. BP (Figure $5 \mathrm{a}, \mathrm{b}$ and $\mathrm{d})$.

This short transitional period occurred over a maximum of 300 years and is characterised by a drop in diatom diversity: $S$. pinnata is almost the only species that persists. This profound change in diatom communities is concomitant with the strongest detrital pulse occurring at $4200 \mathrm{cal}$. BP (Figure 5e). This pulse generated a dilution of the concentration in biogenic silica, and consequently, the flux of diatoms decreased drastically. This period is also marked by high values of $\mathrm{C} / \mathrm{N}$ ratio (Figure 3 ), suggesting high input of both terrestrial minerogenic and organic matter.

This detrital pulse has been interpreted as the erosion of subsurface soil horizons, triggered by more intense and/or more frequent rainfall around 4200 cal. BP (Brisset et al., 2013). This massive increase in allochtonous inputs into Lake Petit necessarily entailed an increase in water turbidity further reinforced by re-suspension of sediments. It can be assumed that high concentrations of suspended mineral particles might, by limiting light penetration in the water column, have reduced photosynthetic activity, diatom development, while enhancing increased conductivity. The persistence of the predominance of $S$. pinnata clearly illustrates that monospecific diatom assemblages might occur in a context of frequent and intense ecological disturbances such as changes in light, nutrient resources and substrate availability (Hayashi, 2011).

\section{From 4100 to 2400 cal. BP:Towards a new equilibrium}

In the wake of the detrital pulse, diatom productivity decreases significantly, while the aquatic ecosystem is still undergoing diversification, as illustrated by the increase in the equitability diversity index (Figure 3). The decrease in diatom production occurs synchronously with an increase in minerogenic detrital input. It may be inferred from this that the persistence of turbidity in the lake waters is likely to have reduced photosynthetic activity. Moreover, during this period, Lake Petit was surrounded by cambisol-type soils under more open vegetation (Brisset et al., 2013). As a result, soluble elements and organic terrestrial matter inputs (and therefore nutrient inputs) decreased significantly from $4100 \mathrm{cal}$. BP. The decrease in diatom productivity over this period could also be related to this decrease in nutrient inputs.

It must be noted that such interactions between nutrient lowering in lakes and the development of open landscapes have been previously evidenced in the multi-proxy study of Lake Unterer Landschitzsee in the Central Austrian Alps (Schmidt et al., 2002). These authors argued that vegetation changes from forest to grassland and the disappearance of a humus layer might have led to a reduction of organic sourcing of lake fertilisation.

Interestingly, these changes in diatom productivity also correspond to the development of the green alga Pediastrum boryanum, which is typically dominant in subarctic lakes and related to low dissolved organic carbon content (Weckström et al., 2010). Differences in competitive abilities for nutrient resources (e.g. light, Si, N and P) classically control species composition, diversity and succession of algal communities (Tilman, 1986). Thus, the coexistence of diatoms and Pediastrum in Lake Petit might have increased competition for resources, especially for light and nutrients. Lastly, in Lake Sägistalsee (1935 m a.s.1.) in the Swiss Alps, Hofmann (2003) noted an increase in cladoceran diversity related to a large range of shoreline habitats during a period of more open vegetation. If we assume that a similar diversification of primary consumers (such as cladocerans/copepods) occurred in Lake Petit, zooplankton grazing of the 'small-sized' Fragilaria might have been an additional factor in lowering diatom productivity. 
The increase in the equitability diversity index (Figure 3 ) indicates that diatom assemblages were more diversified, leading to the assumption that a larger variety of habitats were available. Diatoms may have taken advantage of possible substrate variability, such as variations in substrate surface roughness, or the existence of gravel beaches or zones of macroalgae surrounding the lake (Downes et al., 1998). Diversity might also have been enhanced by further perturbations (e.g. re-suspension of sediments) due to soil erosion.

\section{From 2400 to the present: More subtle ecosystem changes}

This period is characterised by the expansion of growing epilithic and epiphytic diatoms, suggesting that diversification of habitats is possibly linked to the increase in macrophyte vegetation. In parallel, the development of neutrophilous (e.g. E. minutum and $S$. pupula) and meso-eutrophic taxa (e.g. S. pupula, N. radiosa and $S$. construens var. venter) is associated with the weak increase in diatom productivity, which is also concomitant with nutrient enrichment (higher values of TOC and TN). This presupposes a general trend of lake acidification and nutrient enrichment during this period. From 800 cal. BP, higher abundances of $S$. pinnata and $S$. construens var. venter and an increase in diatom productivity (remaining lower than between 4800 and 4300 cal. BP) are observed. These recent changes are contemporaneous with several attempts at rural water resource management that have modified Lake Petit and other upstream lakes. These management projects include water supply galleries dug between AD 1820 and 1823 and the now-decommissioned AD 1947 dam (Figure 1). Even if hydraulic engineers did not attain their initial objectives, these activities have certainly modified connectivity between lakes, in terms, for instance, of changes in their water levels and water budgets, but estimating the potential impact of such changes in algal communities remains a difficult task and requires higher resolution analysis.

\section{Discussion}

We have shown that the two major states, separated by a tipping point before and after $4200 \mathrm{cal}$. BP, that characterised the lacustrine ecosystem trajectories of Lake Petit were primarily linked to local landscape forcing. More subtle changes occur after this date. In this section, we first discuss whether such a response may have been controlled by abrupt or progressive climatic forcing. Following this, we examine the role of long-term human pressures in triggering an aquatic ecosystem-specific trajectory.

\section{Climate-driven ecosystem changes}

Several studies have addressed the potential of diatom ecology for palaeoclimatic studies in circumpolar and alpine lakes rich in Fragilariaceae taxa. Even if diatom distribution is primarily determined by regional water chemistry, climatic gradients also influence algal communities (Laing and Smol, 2000; Lotter et al., 1997; Schmidt et al., 2004). The regime shift in local ecosystems such as that of Lake Petit, might be connected with (1) an abrupt climatic reverse during the $4200 \mathrm{cal}$. BP event and (2) a low-frequency climate regime shift at the mid-late Holocene transition (ca. 4000-3000 cal. BP).

Role of abrupt climate change. Comparison between the Lake Petit record and other palaeoenvironmental proxies strongly suggests a close link between the regime shift in ecosystems around 4200 cal. BP and climatic forcing. This regime shift in Lake Petit might be linked with the rapid climatic oscillation at $4200 \mathrm{cal}$. BP identified in the Northern Hemisphere (Booth et al., 2005; Huang et al., 2011; Magny et al., 2009, 2012b; Staubwasser et al., 2003) and in the Mediterranean basin (Bruneton et al., 2002; Drysdale et al., 2006; Miramont et al., 2008; Roberts et al., 2011). This climatic event is contemporaneous with increases in water levels in Lakes Cerin (Figure 5h) and Bourget (Magny et al., 2012a) in Western Europe and Saint-Léger (Digerfeldt et al., 1997; Figure 5g), Ledro and Accesa (Magny et al., 2012b) in the Northern Mediterranean.

In Lake Petit, the important change in diatom assemblages between 4300 and $4100 \mathrm{cal}$. BP is contemporaneous with a major detrital pulse. Monospecific diatom assemblages ( $S$. pinnata) and low diatom productivity could indicate that the lacustrine ecosystem was profoundly constrained by this disturbance. Runoff, by increasing water turbidity, could be a straightforward explanation for the drop in diatom productivity. This argues that more intense and/or more frequent rainfall occurred (Brisset et al., 2013). Regarding these results, it seems that climate has acted mainly as an indirect forcing agent on the lacustrine regime shift by initiating sudden soil erosion processes. These aspects illustrate well abrupt regime shifts due to variations in abiotic parameters in such fragile mountain environments.

Role of trend in climate change. Apart from the abrupt regime shift, a progressive decline in diatom productivity from 4800 to 3600 cal. BP occurs in Lake Petit, which may suggest a long-term effect of changing climate on ecosystem functioning. The highest productivity period (from 4800 to $4300 \mathrm{cal}$. BP) is related to a distinct dominance of $S$. pinnata, which is typically associated with high lake water alkalinity and elevated summer water temperatures (Michelutti et al., 2007; Pienitz et al., 1995; Podritske and Gajewski, 2007). In alpine environments, warmer periods have been linked to high lake water $\mathrm{pH}$ (Larsen et al., 2006; Michelutti et al., 2007; Psenner and Schmidt, 1992; Wolfe, 2002) and to high diatom productivity through a lengthening of the growing season (Lotter and Bigler, 2000; Smol et al., 2005). Cremer et al. (2001) notably identified an abundance of $S$. pinnata during the Holocene Climatic Optimum at Lake Basaltsø (East Greenland) and concluded that this diatom likely reflected an increase in lake productivity and higher lake water temperatures. We may, thus, interpret the long-term decrease in diatom productivity highlighted by the drop in $S$. pinnata frequencies as a progressive decline in the length of the growing season from the end of the Holocene Climatic Optimum until about 3600 cal. BP, probably due to an increase in ice cover duration and/or lower temperatures that reduce diatom growth. A progressive cooling from 4500 to $3300 \mathrm{cal}$. BP has been shown in the Austrian Alps based on a reconstruction of summer air temperatures inferred from chironomid assemblages at Lake Schwarzsee ob Sölden (Ilyashuk et al., 2011). This may be in agreement with the generally accepted fact that the mid-late Holocene transition (4200 cal. BP according to Walker et al. (2012)) would have been characterised by an increase in humidity and cooler temperatures as evidenced by the glacier advances of the Neoglacial period (Goehring et al., 2012; Holzhauser et al., 2005) and treeline regression (Nicolussi et al., 2005).

Starting from $3600 \mathrm{cal}$. BP, diatom productivity increases again from 2000 to $1500 \mathrm{cal}$. BP. In like manner, the rise in diatom productivity added to $S$. pinnata development might be a consequence of a longer growing season. This hypothesis is consistent with the glacier retreat phase in the western Alps during this period (Deline and Orombelli, 2005).

Finally, regarding the 'Little Ice Age', the most recent cold phase, well known in the historical corpus (Pichard and Roucaute, 2014) and by tree-ring growth studies (Corona et al., 2011), there is no evidence of change in diatom assemblages nor of a drop in 
diatom fluxes in Lake Petit that may allow for an unequivocal recognition of this climate oscillation.

\section{Human-induced changes in ecosystem functioning}

Even if the main ecosystem change dated at 4200 cal. BP certainly appears as climatically driven, ecosystem responses since this date have been more subtle and have not been unequivocally attributed to climatic forcing. The weak increase in diatom productivity and the more meso-eutrophic species suggest that nutrient enrichment occurs from 2400 to $800 \mathrm{cal}$. BP (Figure 5c and d). This period is not strictly concomitant with a change in vegetation cover in the catchment. Indeed, the frequency of detrital inputs and of ruderal-anthropogenic pollen taxa had progressively increased since $4100 \mathrm{cal}$. BP. More noteworthy is the continuous presence and the increase in nitrophilous pollen taxa (e.g. Urtica and Mentha) from $2500 \mathrm{cal}$. BP, which indicates nitrogen enrichment of soils of the Lake Petit catchment related to intensive local grazing (Figure 5e).

Pollen evidence is supported by archaeological investigations (Suméra et al., 2008) revealing the presence of several pastoral enclosures in the Lake Petit catchment (Figure 1). Transhumant grazing since about the Neolithic period, around 7000 cal. BP, is recognised in pollen diagrams of the Southern Alps (Brisset et al., 2015; Walsh et al., 2014). Pastoral activities may alter alpine ecosystems by producing strong heterogeneities in the distribution of plant species and soil nutrients (Rossignol et al., 2006; Schrama et al., 2013; Singer and Schoenecker, 2003). Specifically, soil nutrient enrichment occurs principally along paths, in domestic livestock resting areas and inside pastoral enclosures. As nutrient transfers from pastures to water bodies occur as particulate nitrogen and organic phosphorus transported by runoff (Kurz et al., 2006), the rise in diatom productivity might have been significantly controlled by anthropogenic-induced nutrient input. Subsequently, diatom productivity decreased at 1300 cal. BP, while more soil erosion occurred in a catchment that had probably become treeless (Brisset et al., 2013).

While pollen data suggest an intensification of human impacts from $1300 \mathrm{cal}$. BP, diatom assemblages have remained relatively stable. Diatom assemblages indeed tend to show a new equilibrium in the status of the lake, thus suggesting that human pressures were sufficiently buffered by the aquatic ecosystem to preclude another regime shift.

\section{Can we define 'relevant baseline conditions' for Lake Petit?}

Present-day management of aquatic ecosystems is often focused on (1) actions aimed at reversing environmental impacts inferred by the identification of specific disequilibrium (such as eutrophication or loss in diversity) and (2) conservation strategies of both biodiversity and habitats. In this framework, one of the major concerns is the integration of palaeoecology within conservation strategies as a key to understanding biotic and abiotic processes prior to anthropisation (Seddon et al., 2014). For instance, the crucial question of algal biodiversity changes implies acquisition of knowledge beyond ecological monitoring records. Therefore, taking into account long timescales requires enhanced understanding of complex ecosystem changes (especially interactions between terrestrial and lacustrine components), and biogeochemical or nutrient cycling (with the role of surrounding soils and of geology of catchment areas), both of which are rather poorly understood (Geist, 2011).

The palaeoecological study of Lake Petit offers a priori the opportunity to access, retrospectively, this knowledge and to reconstruct pre-anthropogenic lacustrine dynamics. If we assume, regarding diatom assemblages, that Lake Petit has not been significantly influenced by human activities prior to about 2400 cal. BP, we must acknowledge, however, that humans might have exacerbated the effect of climate on the watershed from $4200 \mathrm{cal}$. $\mathrm{BP}$, via changes in vegetation and sensitivity to erosion, and consequently nutrient sourcing of the lake. Altogether, disentangling the influence of human activities and climate in such regime shift remains difficult since the effects of both are probably superimposed.

Furthermore, the choice of reference conditions implies somehow a 'freeze' of the ecosystem state in its past trajectory regardless of any chaotic event or any unpredictable ecosystem response to external forcing. Yet, as pointed out in a recent review (VegasVilarrúbia et al., 2011), large palaeoecological datasets enable gauging the capacity of 'rare events' in generating ecosystem shifts between 'stable states'. Specifically, data collected at Lake Petit provide a good example of rapid change in the structuring of diatom diversity and habitats triggered by an abrupt event at 4200 cal. BP and by further small incremental changes triggered by human activities beyond a critical threshold.

\section{Conclusion}

Diatom assemblages, organic composition of sediments and Pediastrum boryanum concentrations have revealed the lacustrine dynamics of Lake Petit since $5000 \mathrm{cal}$. BP. Our study has shown, in particular, that diatom assemblages responded rapidly to environmental changes allowing a better understanding of the forcing involved in the tipping point of this alpine environment at $4200 \mathrm{cal}$. BP. Our results have highlighted the following:

1. From 4800 to 4300 cal. BP, Lake Petit was a stable diatom-productive ecosystem dominated by S. pinnata, a species encountered in alkaline lakes and related to relatively high summer water temperatures. Nutrient and cation supply were provided by chemical weathering of podzol-type soils under conifer woodlands;

2. This overall stability was interrupted following a sudden drop in diatom diversity and productivity between 4300 and $4100 \mathrm{cal}$. BP in response to a major detrital pulse during the climatic oscillation associated with this event;

3. From 4100 to 2400 cal. BP, diatom productivity decreased and Pediastrum boryanum developed during the onset of the Neoglacial period. Diatom assemblages, subjected to terrigenous inputs from continuous erosion of pasture soils, were more diversified and mainly dominated by $P$. robusta, P. brevistriata and P. pseudoconstruens;

4. Finally, from $2400 \mathrm{cal}$. BP to the present day, diatom assemblages show a slight acidification and enrichment of waters concomitant with increased human pressures in the catchment.

The tipping point in soil dynamics, following soil weakening by erosion processes favoured by deforestation, was reached at $4200 \mathrm{cal}$. BP probably due to a rapid change in precipitation regime. Soil destabilisation led, through a cascading set of responses, to a new lasting ecosystem state in Lake Petit. These conclusions illustrate the close link between ecosystems and how disturbance can propagate among all compartments of alpine catchments. In comparison, the increase in anthropogenic pressure in the Lake Petit catchment since 3000 cal. BP did not lead to a major regime shift. However, changes in $\mathrm{pH}$ and nutrient enrichment are recorded by diatom assemblages and might be an indirect response to pastoral activities in the catchment. Lower temperatures since 4200 cal. BP suggested by diatom assemblages could have participated in landscape changes by limiting soil formation and forest recovery. This climatic influence, in conjunction with increasing human pressure, certainly 
contributed to the irreversible changes in both the terrestrial and lacustrine ecosystems. Regarding these results, we can ask the question as to whether recent forest recovery and decline in pastoralism could lead to a Lake Petit ecosystem similar to that of the period 4800-4200 cal. BP. Finally, taking into account long timescales in environmental management requires an enhanced understanding of complex ecosystem interactions. The results obtained at Lake Petit provide a good example of an abrupt regime shift of such fragile mountain systems in response to a rapid climatic event at 4200 cal. BP, further compounded by minor incremental changes triggered by human activities beyond a critical threshold.

\section{Acknowledgements}

Coring of Lake Petit (in 2009 and 2012) was rendered possible thanks to F. Arnaud (EDYTEM), C. Giguet-Covex (LECA), E. Malet (EDYTEM), J. Pansu (LECA), J. Poulenard (EDYTEM) and B. Wilhelm (University of Bern). We thank Jean-Charles Mazur for his help. We thank an anonymous reviewer for improvements to the manuscript.

\section{Funding}

This study has benefited from funding by the 'Programme d'Intérêt Transfrontalier Mercantour' (Parc National du Mercantour, France) coordinated by F. Suméra and the ECCOREV Research Federation (HOMERE program). Rosine Cartier benefited from a $\mathrm{PhD}$ grant from the French Ministry of Education and Elodie Brisset from a PhD grant by Région PACA (France).

\section{References}

Alefs J and Müller J (1999) Differences in the eutrophication dynamics of Ammersee and Starnberger See (Southern Germany), reflected by the diatom succession in varve-dated sediments. Journal of Paleolimnology 21(4): 395-407.

Balter M (2013) Archaeologists say the 'Anthropocene' is here - But it began long ago. Science 340(6130): 261-262.

Battarbee RW, John Anderson N, Jeppesen E et al. (2005) Combining palaeolimnological and limnological approaches in assessing lake ecosystem response to nutrient reduction. Freshwater Biology 50(10): 1772-1780.

Battarbee RW, Morley D, Bennion H et al. (2011) A palaeolimnological meta-database for assessing the ecological status of lakes. Journal of Paleolimnology 45(4): 405-414.

Battarbee RW, Thompson R, Catalan J et al. (2002) Climate variability and ecosystem dynamics of remote alpine and arctic lakes: The MOLAR project. Journal of Paleolimnology 28(1): 1-6.

Beniamino C (2006) Le Valdeblore et l'eau des lacs des Millefonts. Patrimoines du Haut Pays 7: 78-82.

Beniston M (2003) Climatic change in mountain regions: A review of possible impacts. Climatic Change 59(1-2): 5-31.

Beniston M (2006) Mountain weather and climate: A general overview and a focus on climatic change in the alps. Hydrobiologia 562(1): 3-16.

Bennett KD (1990) Textbook of pollen analysis. K. Faegri, J. Iversen (4th edn by K. Faegri, P.E. Kaland, K. Krzywinski), John Wiley and Sons, Chichester 1989 (328 pp). Journal of Quaternary Science 5(3): 254-255.

Bennett KD (1996) Determination of the number of zones in a biostratigraphical sequence. New Phytologist 132(1): 155170.

Bennion H and Battarbee R (2007) The European Union Water Framework Directive: Opportunities for palaeolimnology. Journal of Paleolimnology 38(2): 285-295.

Bennion H and Simpson GL (2011) The use of diatom records to establish reference conditions for UK lakes subject to eutrophication. Journal of Paleolimnology 45(4): 469-488.
Bennion H, Appleby PG and Phillips GL (2001) Reconstructing nutrient histories in the Norfolk Broads, UK: Implications for the role of diatom-total phosphorus transfer functions in shallow lake management. Journal of Paleolimnology 26(2): 181-204.

Bennion H, Battarbee RW, Sayer CD et al. (2011) Defining reference conditions and restoration targets for lake ecosystems using palaeolimnology: A synthesis. Journal of Paleolimnology 45(4): 533-544.

Berglund BE (2011) How mankind has shaped European nature. Vegetation History and Archaeobotany 20(1): 79-81.

Bigler C, Heiri O, Krskova R et al. (2006) Distribution of diatoms, chironomids and cladocera in surface sediments of thirty mountain lakes in south-eastern Switzerland. Aquatic Sciences 68(2): 154-171.

Birks HH and Birks HJB (2006) Multi-proxy studies in palaeolimnology. Vegetation History and Archaeobotany 15(4): 235-251.

Birks HJB and Line JM (1992) The use of rarefaction analysis for estimating palynological richness from quaternary pollenanalytical data. The Holocene 2(1): 1-10.

Booth RK, Jackson ST, Forman SL et al. (2005) A severe centennial-scale drought in midcontinental North America 4200 years ago and apparent global linkages. The Holocene 15(3): 321-328.

Brisset E, Guiter F, Miramont C et al. (2012) Approche multidisciplinaire d'une séquence lacustre holocène dans les alpes du sud au Lac Petit (Mercantour, alt. 2 200m, France): Histoire d'un géosystème dégradé. Quaternaire. Revue de l'Association française pour l'étude du Quaternaire 23(4): 309-319.

Brisset E, Guiter F, Miramont C et al. (2015) Lateglacial/Holocene environmental changes in the Mediterranean Alps inferred from lacustrine sediments. Quaternary Science Reviews 110: 49-71.

Brisset E, Miramont C, Guiter F et al. (2013) Non-reversible geosystem destabilisation at $4200 \mathrm{cal}$. BP: Sedimentological, geochemical and botanical markers of soil erosion recorded in a Mediterranean alpine lake. The Holocene 23: 1863-1874.

Bruneton H, Provensal M, Devillers B et al. (2002) Relations entre paléohydrologie et morphogenèse holocènes des petits et moyens bassin-versants en basse Provence et Languedoc oriental. Les fleuves ont une histoire: Paléo-environnement des rivières et des lacs français depuis 15000 ans. In: Bravard J-P and Magny M (eds) Histoire des rivières et des lacs de Lascaux à nos jours. Paris: Errance, pp. 259-267.

Carstensen J, Telford RJ and Birks HJB (2013) Diatom flickering prior to regime shift. Nature 498(7455): E11-E12.

Catalan J, Ventura M, Brancelj A et al. (2002) Seasonal ecosystem variability in remote mountain lakes: Implications for detecting climatic signals in sediment records. Journal of Paleolimnology 28(1): 25-46.

Connell JH (1978) Diversity in tropical rain forests and coral reefs. Science 199(4335): 1302-1310.

Corona C, Edouard J-L, Guibal F et al. (2011) Long-term summer (AD751-2008) temperature fluctuation in the French Alps based on tree-ring data. Boreas 40: 351-366.

Cremer H, Melles M and Wagner B (2001) Holocene climate changes reflected in a diatom succession from Basaltsø, East Greenland. Canadian Journal of Botany 79(6): 649-656.

Dam HV, Mertens A and Sinkeldam J (1994) A coded checklist and ecological indicator values of freshwater diatoms from The Netherlands. Netherland Journal of Aquatic Ecology 28(1): 117-133.

Dearing JA (2013) Why future earth needs lake sediment studies. Journal of Paleolimnology 49(3): 537-545.

De Beaulieu J-L (1977) Contribution pollenanalytique à l'histoire tardiglaciaire et Holocène de la végétation des Alpes méri- 
dionales françaises. Unpublished Thesis, Aix-Marseille Université, $358 \mathrm{pp}$.

Deline P and Orombelli G (2005) Glacier fluctuations in the western Alps during the Neoglacial, as indicated by the Miage morainic amphitheatre (Mont Blanc massif, Italy). Boreas 34(4): 456-467.

De Lumley $\mathrm{H}$ and Echassoux A (2009) Les gravures rupestres du Chalcolithique et de l'âge du Bronze ancien de la région du mont Bego. Les mythes cosmogoniques des premiers peuples métallurgistes des Alpes méridionales. L'Anthropologie 113(5, Part 2): 969-1004.

Digerfeldt G, de Beaulieu J-L, Guiot J et al. (1997) Reconstruction and paleoclimatic interpretation of Holocene lake-level changes in Lac de Saint-Leger, Haute-Provence, southeast France. Palaeogeography, Palaeoclimatology, Palaeoecology 136(1-4): 231-258.

Downes BJ, Lake PS, Schreiber ESG et al. (1998) Habitat structure and regulation of local species diversity in a stony, upland stream. Ecological Monographs 68(2): 237-257.

Druart JC, Dorioz JM, Blanc $\mathrm{P}$ et al. (1999) Un lac à protéger: Le lac Bénit (Haute-Savoie). Revue de Géographie Alpine 3: 87-99.

Drysdale R, Zanchetta G, Hellstrom J et al. (2006) Late Holocene drought responsible for the collapse of Old World civilizations is recorded in an Italian cave flowstone. Geology 34(2): 101-104.

Durand Y, Giraud G, Laternser M et al. (2009) Reanalysis of 47 years of climate in the French Alps (1958-2005): Climatology and trends for snow cover. Journal of Applied Meteorology and Climatology 48(12): 2487-2512.

Fallu M-A, Allaire N and Pienitz R (2000) Freshwater Diatoms from Northern Québec and Labrador (Canada): SpeciesEnvironment Relationships in Lakes of Boreal Forest, ForestTundra and Tundra Regions. Berlin: J. Cramer, 200 pp.

Filippelli GM, Souch C, Menounos B et al. (2006) Alpine lake sediment records of the impact of glaciation and climate change on the biogeochemical cycling of soil nutrients. Quaternary Research 66(1): 158-166.

Finkelstein SA and Gajewski K (2008) Responses of Fragilarioid-dominated diatom assemblages in a small Arctic lake to Holocene climatic changes, Russell Island, Nunavut, Canada. Journal of Paleolimnology 40(4): 1079-1095.

Finsinger W (2001) Vegetation history and human impact at the Lago del Vei del Bouc (Argentera Massif, Maritime Alps). Quaternaire 12: 223-233.

Fritz SC (2008) Deciphering climatic history from lake sediments. Journal of Paleolimnology 39(1): 5-16.

Gandouin E and Franquet E (2002) Late Glacial and Holocene chironomid assemblages in Lac Long Inférieur (southern France, $2090 \mathrm{~m}$ ): Palaeoenvironmental and palaeoclimatic implications. Journal of Paleolimnology 28(3): 317-328.

Geist J (2011) Integrative freshwater ecology and biodiversity conservation. Ecological Indicators 11(6): 1507-1516.

Goehring BM, Vacco DA, Alley RB et al. (2012) Holocene dynamics of the Rhone Glacier, Switzerland, deduced from ice flow models and cosmogenic nuclides. Earth and Planetary Science Letters 351-352: 27-35.

Grimm EC (1987) CONISS: A FORTRAN 77 program for stratigraphically constrained cluster analysis by the method of incremental sum of squares. Computers \& Geosciences 13(1): 13-35.

Guilizzoni P, Marchetto A, Lami A et al. (2011) Use of sedimentary pigments to infer past phosphorus concentration in lakes. Journal of Paleolimnology 45(4): 433-445.

Haworth EY (1976) Two late-glacial (late devensian) diatom assemblage profiles from Northern Scotland. New Phytologist 77(1): 227-256.
Hayashi T (2011) Monospecific planktonic diatom assemblages in the Paleo-Kathmandu Lake during the middle Brunhes Chron: Implications for the paradox of the plankton. Palaeogeography, Palaeoclimatology, Palaeoecology 300(1-4): 46-58.

Heiri O and Lotter AF (2003) 9000 years of chironomid assemblage dynamics in an Alpine lake: Long-term trends, sensitivity to disturbance, and resilience of the fauna. Journal of Paleolimnology 30(3): 273-289.

Hofmann W (2003) The long-term succession of high-altitude cladoceran assemblages: A 9000-year record from Sägistalsee (Swiss Alps). Journal of Paleolimnology 30(3): 291-296.

Holzhauser H, Magny M and Zumbuühl HJ (2005) Glacier and lake-level variations in west-central Europe over the last 3500 years. The Holocene 15(6): 789-801.

Huang CC, Pang J, Zha X et al. (2011) Extraordinary floods related to the climatic event at 4200 a BP on the Qishuihe River, middle reaches of the Yellow River, China. Quaternary Science Reviews 30(3-4): 460-468.

Hustedt F (1943) Die Diatomeenflora einiger Hochgebirgsseen der Landschaft um Davos in den Schweizer Alpen. Archiv für Hydrobiologie 43:pp. 124-197.

Ilyashuk EA, Koinig KA, Heiri O et al. (2011) Holocene temperature variations at a high-altitude site in the Eastern Alps: A chironomid record from Schwarzsee ob Sölden, Austria. Quaternary Science Reviews 30(1-2): 176-191.

Juggins S (2007) C2: Software for Ecological and Palaeoecological Data Analysis and Visualisation (User Guide Version 1.5). Newcastle upon Tyne: Newcastle University, 77 pp.

Juggins S (2012) rioja: Analysis of Quaternary Science Data (R package version (0.8-5)). Available at: http://cran.r-project. org/web/packages/rioja/index.html

Kamenik C, Schmidt R, Kum G et al. (2001) The influence of catchment characteristics on the water chemistry of mountain lakes. Arctic, Antarctic, and Alpine Research 33: 404-409.

Komárek J and Jankovská V (2001) Review of the Green Algal Genus Pediastrum: Implication for Pollen-Analytical Research. Berlin: J. Cramer, 127 pp.

Krammer K and Lange-Bertalot H (1986-1991) Bacillariophyceae. Süsswasserflora von Mitteleuropa, 2/1-2/4. G. Stuttgart: Fischer Verlag.

Kurz I, O'Reilly CD and Tunney H (2006) Impact of cattle on soil physical properties and nutrient concentrations in overland flow from pasture in Ireland. Agriculture, Ecosystems \& Environment 113(1-4): 378-390.

Laing TE and Smol JP (2000) Factors influencing diatom distributions in circumpolar treeline lakes of Northern Russia. Journal of Phycology 36(6): 1035-1048.

Larocque I and Finsinger W (2008) Late-glacial chironomidbased temperature reconstructions for Lago Piccolo di Avigliana in the southwestern Alps (Italy). Palaeogeography, Palaeoclimatology, Palaeoecology 257(1-2): 207-223.

Larsen J, Jones VJ and Eide W (2006) Climatically driven $\mathrm{pH}$ changes in two Norwegian alpine lakes. Journal of Paleolimnology 36(2): 175-187.

Likens GED, Driscoll CT and Buso DC (1996) Long-term effects of acid rain: Response and recovery of a forest ecosystem. Science 272(5259): 244-246.

Lotter AF and Bigler C (2000) Do diatoms in the Swiss Alps reflect the length of ice-cover? Aquatic Sciences 62(2): 125141.

Lotter AF and Birks HJB (2003) The Holocene palaeolimnology of Sägistalsee and its environmental history - A synthesis. Journal of Paleolimnology 30(3): 333-342.

Lotter AF, Birks HJB, Hofmann W et al. (1997) Modern diatom, cladocera, chironomid, and chrysophyte cyst assemblages as quantitative indicators for the reconstruction of past environ- 
mental conditions in the Alps. I. Climate. Journal of Paleolimnology 18(4): 395-420.

Lotter AF, Pienitz R and Schmidt R (1999) Diatoms as indicators of environmental change near Arctic and Alpine treeline. In: Stoermer EF and Smol JP (eds) The Diatoms: Applications for the Environmental and Earth Sciences. Cambridge: Cambridge University press, pp. 205-226.

McLauchlan KK, Williams JJ and Engstrom DR (2013) Nutrient cycling in the palaeorecord: Fluxes from terrestrial to aquatic ecosystems. The Holocene 23(11): 1635-1643.

Magny M, Arnaud F, Billaud Y et al. (2012a) Lake-level fluctuations at Lake Bourget (eastern France) around 4500-3500 cal. a BP and their palaeoclimatic and archaeological implications. Journal of Quaternary Science 27(5): 494-502.

Magny M, Joannin S, Galop D et al. (2012b) Holocene palaeohydrological changes in the northern Mediterranean borderlands as reflected by the lake-level record of Lake Ledro, northeastern Italy. Quaternary Research 77(3): 382-396.

Magny M, Vannière B, Zanchetta G et al. (2009) Possible complexity of the climatic event around 4300-3800 cal. BP in the central and western Mediterranean. The Holocene 19(6): 823-833.

Marciniak B (1988 [1986]) Late glacial Fragilaria flora from lake sediments of the Tatra Mts. and the Alps. In: Round FE (ed.) Proceedings of the ninth international diatom symposium, Bristol, 24-30 August 1986, pp. 233-243. Bristol:Biopress Limited.

Meyers PA and Teranes JL (2001) Sediment organic matter. In: Last WM and Smol JP (eds) Tracking Environmental Change Using Lake Sediments, Developments in Paleoenvironmental Research. Dordrecht: Springer, pp. 239-269.

Michelutti N, Wolfe AP, Briner JP et al. (2007) Climatically controlled chemical and biological development in Arctic lakes. Journal of Geophysical Research: Biogeosciences 112(G3): G03002.

Miramont C, Boutterin C, Sivan O et al. (2008) Grandes séquences et principales ruptures morphogéniques en Haute Provence les complexes sédimentaires des petits organismes torrentiels de moyenne Durance. Cahiers de Paléoenvironnement 6: 145-154.

Morin D and Rosenthal P (2002) Mines et métallurgie du fer en Provence et dans les Alpes du Sud, département des AlpesMaritimes. Commune de Saint-Dalmas, Valdeblore. Etude diachronique des vestiges d'exploitation minière et de métallurgie du fer, prospection au sol. Aix-en-Provence: Service Régionale de l'Archéologie, Direction Régionale des Affaires culturelle de la Région Provence-Alpes-Cotes d'Azur, 19 pp.

Nicolussi K, Kaufmann M, Patzelt G et al. (2005) Holocene treeline variability in the Kauner Valley, Central Eastern Alps, indicated by dendrochronological analysis of living trees and subfossil logs. Vegetation History and Archaeobotany 14(3): 221-234.

Oksanen J, Kindt R, Legendre P et al. (2007) The vegan package. Community ecology package. Available at: http://cran. r-project.org and https://github.com/vegandevs/vegan

Ortu E, David F and Caramiello R (2003) Rôle de l'homme dans l'histoire de la végétation de la vallée Ellero (Alpes maritimes, Italie). Comptes Rendus Biologies 326(7): 631-637.

Pagès G (2009) Le Clouté, Valdeblore (06). Rapport de fouille programmée. Aix-en-Provence: Service Régionale de Archéologie, Direction Régionale des Affaires culturelle de la Région Provence-Alpes-Cotes d'Azur, 42 pp.

Pichard G and Roucaute E (2014) Sept siècles d'histoire hydroclimatique du Rhône d'Orange à la mer (1300-2000): Climat, crues, inondations (Hors-série de la revue Méditerranée). Aix-en-Provence: Presses Universitaires de Provence, 194 pp.
Pienitz R, Smol JP and Birks HJB (1995) Assessment of freshwater diatoms as quantitative indicators of past climatic change in the Yukon and Northwest Territories, Canada. Journal of Paleolimnology 13(1): 21-49.

Podritske B and Gajewski K (2007) Diatom community response to multiple scales of Holocene climate variability in a small lake on Victoria Island, NWT, Canada. Quaternary Science Reviews 26(25-28): 3179-3196.

Ponel P, Court-Picon M, Badura M et al. (2011) Holocene history of Lac des Lauzons (2180 m a.s.1.), reconstructed from multiproxy analyses of Coleoptera, plant macroremains and pollen (Hautes-Alpes, France). The Holocene 21(4): 565-582.

Psenner R and Schmidt R (1992) Climate-driven $\mathrm{pH}$ control of remote alpine lakes and effects of acid deposition. Nature 356(6372): 781-783.

Quesada A, Vincent WF, Kaup E et al. (2006) Landscape control of high latitude lakes in a changing climate. In: Bergstrom DM, Convey P and Huiskes AHL (eds) Trends in Antarctic Terrestrial and Limnetic Ecosystems. Dordrecht: Springer, pp. 221-252.

Randsalu-Wendrup L, Conley DJ, Carstensen J et al. (2014) Combining limnology and palaeolimnology to investigate recent regime shifts in a shallow, eutrophic lake. Journal of Paleolimnology 51(3): 437-448.

Reuss JO, Cosby BJ and Wright RF (1987) Chemical processes governing soil and water acidification. Nature 329(6134): 27-32.

Righi D, Terribile F and Petit S (1999) Pedogenic formation of kaolinite-smectite mixed layers in a soil toposequence developed from basaltic parent material in Sardinia (Italy). Clays and Clay Minerals 47(4): 505-514.

Roberts N, Eastwood WJ, Kuzucuoğlu C et al. (2011) Climatic, vegetation and cultural change in the eastern Mediterranean during the mid-Holocene environmental transition. The Holocene 21(1): 147-162.

Rossignol N, Bonis A and Bouzillé J-B (2006) Consequence of grazing pattern and vegetation structure on the spatial variations of net $\mathrm{N}$ mineralisation in a wet grassland. Applied Soil Ecology 31(1-2): 62-72.

Round FE, Crawford RM and Mann DG (1990) The Diatoms: Biology \& Morphology of the Genera. Cambridge: Cambridge University Press, 768 pp.

Rühland K, Paterson AM and Smol JP (2008) Hemispheric-scale patterns of climate-related shifts in planktonic diatoms from North American and European lakes. Global Change Biology 14(11): 2740-2754.

Scheffer M, Carpenter S, Foley JA et al. (2001) Catastrophic shifts in ecosystems. Nature 413(6856): 591-596.

Scheffer M, Hosper SH, Meijer ML et al. (1993) Alternative equilibria in shallow lakes. Trends in Ecology \& Evolution 8(8): 275-279.

Schindler DW, Hecky RE, Findlay DL et al. (2008) Eutrophication of lakes cannot be controlled by reducing nitrogen input: Results of a 37-year whole-ecosystem experiment. Proceedings of the National Academy of Sciences of the United States of America 105(32): 11254-11258.

Schmidt R, Kamenik C, Kaiblinger C et al. (2004) Tracking Holocene environmental changes in an alpine lake sediment core: Application of regional diatom calibration, geochemistry, and pollen. Journal of Paleolimnology 32(2): 177-196.

Schmidt R, Koinig KA, Thompson R et al. (2002) A multi proxy core study of the last 7000 years of climate and alpine land-use impacts on an Austrian mountain lake (Unterer Landschitzsee, Niedere Tauern). Palaeogeography, Palaeoclimatology, Palaeoecology 187(1-2): 101-120.

Schrama M, Veen GF, Bakker ES et al. (2013) An integrated perspective to explain nitrogen mineralization in grazed 
ecosystems. Perspectives in Plant Ecology, Evolution and Systematics 15(1): 32-44.

Seddon AWR, Mackay AW, Baker AG et al. (2014) Looking forward through the past: Identification of 50 priority research questions in palaeoecology. Journal of Ecology 102(1): 256-267.

Singer FJ and Schoenecker KA (2003) Do ungulates accelerate or decelerate nitrogen cycling? Forest Ecology and Management 181(1-2): 189-204.

Smol JP (1988) Paleoclimate proxy data from freshwater arctic diatoms. International Association of Theoretical and Applied Limnology 23: 837-844.

Smol JP (1992) Paleolimnology: An important tool for effective ecosystem management. Journal of Aquatic Ecosystem Health 1(1): 49-58.

Smol JP and Stoermer EF (2010) The Diatoms: Applications for the Environmental and Earth Sciences. Cambridge: Cambridge University Press, 469 pp.

Smol JP, Wolfe AP, Birks HJB et al. (2005) Climate-driven regime shifts in the biological communities of arctic lakes. Proceedings of the National Academy of Sciences of the United States of America 102(12): 4397-4402.

Sommaruga-Wögrath S, Koinig KA, Schmidt R et al. (1997) Temperature effects on the acidity of remote alpine lakes. Nature 387(6628): 64-67.

Stabell B (1985) The development and succession of taxa within the diatom genus Fragilaria Lyngbye as a response to basin isolation from the sea. Boreas 14(4): 273-286.

Staubwasser M, Sirocko F, Grootes PM et al. (2003) Climate change at the $4.2 \mathrm{ka}$ BP termination of the Indus valley civilization and Holocene south Asian monsoon variability. Geophysical Research Letters 30(8): 1425.

Steffen W, Persson $\AA$, Deutsch L et al. (2011) The anthropocene: From global change to planetary stewardship. AMBIO 40(7): 739-761.

Suméra F, Blanc F, Cavana E et al. (2008) Rapport de sondage, commune de Valdeblore. Rapport final d'opération. Aixen-Provence: Service Régionale de Archéologie, Direction Régionale des Affaires culturelle de la Région ProvenceAlpes-Cotes d'Azur, 30 pp.

Thompson R, Kamenik C and Schmidt R (2005) Ultra-sensitive Alpine lakes and climate change. Journal of Limnology 64(2): 139-152.

Tilman D (1986) Nitrogen-limited growth in plants from different successional stages. Ecology 67(2): 555.
Vegas-Vilarrúbia T, Rull V, Montoya E et al. (2011) Quaternary palaeoecology and nature conservation: A general review with examples from the neotropics. Quaternary Science Reviews 30(19-20): 2361-2388.

Vinebrooke RD and Leavitt PR (1998) Direct and interactive effects of allochthonous dissolved organic matter, inorganic nutrients, and ultraviolet radiation on an alpine littoral food web. Limnology and Oceanography 43(6): 1065-1081.

Vitousek PM and Howarth R (1991) Nitrogen limitation on land and in the sea: How can it occur? Biogeochemistry 13: 87-115.

Walker MJC, Berkelhammer M, Björck S et al. (2012) Formal subdivision of the Holocene Series/Epoch: A discussion paper by a Working Group of INTIMATE (Integration of ice-core, marine and terrestrial records) and the subcommission on quaternary stratigraphy (International Commission on Stratigraphy). Journal of Quaternary Science 27(7): 649-659.

Walsh K, Court-Picon M, de Beaulieu J-L et al. (2014) A historical ecology of the Ecrins (Southern French Alps): Archaeology and palaeoecology of the Mesolithic to the Medieval period. Quaternary International Environmental History of European High Mountains 353,52-73.

Walsh K, Mocci F, Tzortzis S et al. (2007) Dynamique du peuplement et activités agro-pastorales durant l'âge du Bronze dans les massifs du Haut Champsaur et de l'Argentierois (HautesAlpes). Documents d'archéologie méridionale. Protohistoire du Sud de la France 28: 25-44.

Wang R, Dearing JA, Langdon PG et al. (2012) Flickering gives early warning signals of a critical transition to a eutrophic lake state. Nature 492(7429): 419-422.

Weckström K, Weckström J, Yliniemi L-M et al. (2010) The ecology of Pediastrum (Chlorophyceae) in subarctic lakes and their potential as paleobioindicators. Journal of Paleolimnology 43(1): 61-73.

Westover KS, Fritz S, Blyakharchuk TA et al. (2006) Diatom paleolimnological record of Holocene climatic and environmental change in the Altai Mountains, Siberia. Journal of Paleolimnology 35:519-541.

Wögrath S and Psenner R (1995) Seasonal, annual and long-term variability in the water chemistry of a remote high mountain lake: Acid rain versus natural changes. Water, Air, and Soil Pollution 85(2): 359-364.

Wolfe AP (2002) Climate modulates the acidity of Arctic lakes on millennial time scales. Geology 30(3): 215-218. 